\title{
DYNAMICS OF AN ACUTE CORAL DISEASE OUTBREAK ASSOCIATED WITH THE MACROALGAE DICTYOTA SPP. IN DRY TORTUGAS NATIONAL PARK, FLORIDA, USA
}

\author{
Marilyn E Brandt, Benjamin I Ruttenberg, Rob Waara, \\ Jeff Miller, Brian Witcher, Andrew J Estep, \\ and Matt Patterson
}

\begin{abstract}
Reports of coral disease outbreaks have increased in recent decades, but often few details are known about these outbreaks, such as environmental triggers, associated biological variables, or even the precise temporal span of the outbreak. Here we document an acute outbreak of a rapid tissue loss disease on the highest live coral cover $(15 \%-30 \%)$ reefs within Dry Tortugas National Park, Florida, USA. This disease exhibited similar signs to white plague disease with the notable exception that a white film often was observed on the recently denuded skeleton. The temporal span of the disease was short $(<2 \mathrm{mo})$. Partial mortality was recorded but there was no detectable impact to overall coral cover. A significant increase and then decrease in the cover of macroalgae, primarily of the genus Dictyota, occurred simultaneously with the increase and drop in disease lesion density (number of lesions per living tissue area), respectively. No other anomalous biological or physical factors (e.g., unusual temperature, turbidity, passage of storms) corresponded with the outbreak, although it is likely that some environmental anomaly that was undetectable with the methods employed favored both disease and Dictyota expansion. This is the first study to associate a rapid increase in a macroalgal population with a coral disease outbreak. We highlight the need for increased study of the initiation of such outbreaks in the Caribbean.
\end{abstract}

Outbreaks of rapid tissue loss diseases, or "white diseases" (Bythell et al. 2004), have caused significant coral mortality in recent decades and have contributed to the extraordinary loss of living coral cover documented on shallow reefs in the Caribbean (Aronson and Precht 2006). These diseases have included white band disease and white band disease type II on Acropora spp. and white plague types I, II, and III on multiple Caribbean coral species not of the genus Acropora (Sutherland et al. 2004). All of these syndromes present as a distinct line of tissue loss that originates basally or peripherally on an affected colony and progresses rapidly (although rates differ depending on the disease), leaving behind areas of freshly denuded skeleton that appear bright white (reviewed by Bythell et al. 2004). Causal agents have been identified for white plague type II (Richardson et al. 1998b, Denner et al. 2003) and white band type II (Kline and Vollmer 2011), but these pathogens have not appeared in corals with similar disease signs in other parts of the Caribbean, suggesting that the same disease signs may represent multiple etiologies (Pantos et al. 2003, Pollock et al. 2011).

Reports of white disease and other disease outbreaks in reef-building corals have increased dramatically over the last few decades (Weil et al. 2006), though it is unclear whether this is representative of true increases in disease incidence or is the 
result of a greater awareness of disease and an expansion of coral reef monitoring activities (Ward and Lafferty 2004). A disease outbreak is defined as limited or localized increases in disease incidence beyond what is normally expected (Last 2001). In the Caribbean, such limited or localized increases in white disease incidence documented as outbreaks have been associated with the passage of storms (Miller and Williams 2007) and with abnormal thermal events (Miller et al. 2009), but several documented outbreaks have ocurred without any detectable or obvious environmental initiate (e.g., Croquer et al. 2003, Williams and Miller 2005). In the same time period, a dramatic decline in living coral cover and an increase in the abundance of macroalgae have been documented on shallow Caribbean reefs (Hughes 1994, Gardner et al. 2003). Manipulative studies have determined that at least one white disease, white plague type II, can be transmitted through the transplantation of macroalgae between infected colonies and apparently healthy colonies (Nugues et al. 2004). Other recent studies also suggest that macroalgae may play a role in influencing the abundance and diversity of microbial activity on reefs and could be directly contributing to the increased incidence of disease and mortality in corals (Smith et al. 2006, Dinsdale et al. 2008, Haas et al. 2010).

During a coral reef monitoring study in June 2008, an outbreak of a rapid tissue loss disease conforming to the general description of white plague disease was identified in Dry Tortugas National Park (DTNP), Florida, USA. Gross disease signs differed from those described for the diseases white plague types II and III (Richardson et al. 1998a,b, 2001) and we therefore referred to it as the "Tortugas multispecies rapid tissue loss disease" (TMRTL) following the disease naming recommendations of Work and Aeby (2006). Here, we document the in situ dynamics of TMRTL, which tightly corresponded with those of the brown macroalgae genus Dictyota, and we discuss our results in context of potential linkages. We also discuss its associations with other environmental factors to provide baseline information for this disease, which may be an important source of mortality on reefs of DTNP. Results of this study and others like it can be used to better understand why outbreaks occur and whether they are occurring at increasing rates.

\section{Methods}

Location of Study Sites and Monitoring Methods.-The Dry Tortugas region is located over $100 \mathrm{~km}$ to the west of the inhabited islands of the Florida Keys. Land area in DTNP includes seven small keys (Loggerhead, Garden, Bush, Long, East, Hospital, and Middle), but the remaining area of the park $(>95 \%)$ is composed of marine habitats, including some extensive areas of coral reef development. The outbreak was encountered while resurveying permanent sites throughout the park that had been installed the previous month (May) and were being monitored for changes in benthic cover including coral and macroalgae cover. Major disease activity had almost entirely ceased when we returned for follow-up surveys in July 2008, making it a temporally acute outbreak.

Eighteen randomly located permanent monitoring sites were installed on hard reef substrate within the boundaries of DTNP between 12 and 31 May, 2008 (Fig. 1, Table 1). At each site, four permanent $10-\mathrm{m}$ transects (marked with pins) were installed in each of the four cardinal directions, with a $10 \mathrm{~m}$ buffer from a central point (located using GPS and a weighted float line). Since most reefs in DTNP have virtually no slope, all four transects at a site were located at the same depth. Immediately after installation and on each subsequent site visit, transect tapes were attached to the start and end points marking each transect. Video was recorded along the transect, approximately $40 \mathrm{~cm}$ above the substrate, resulting in a $10 \times 0.4$ 


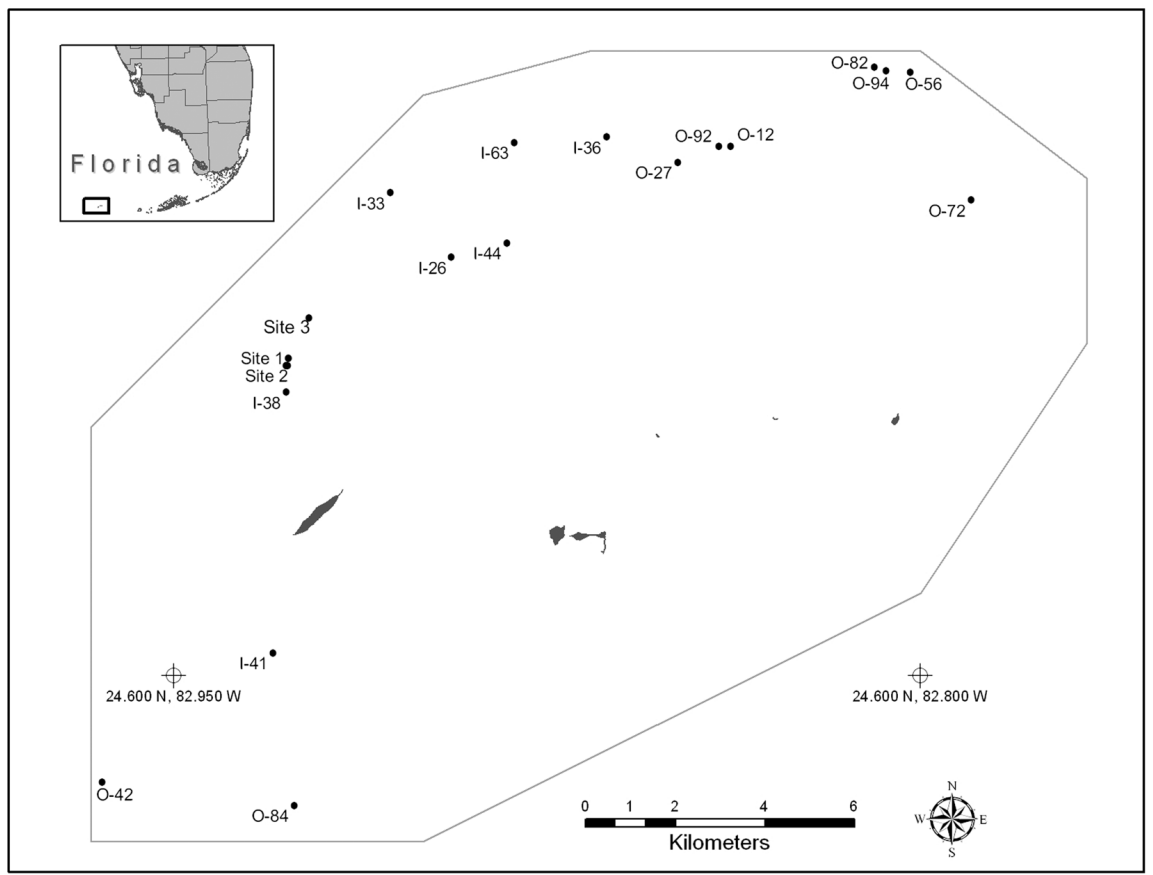

Figure 1. Map of Dry Tortugas National Park site locations. Inset: Location of Dry Tortugas National Park to the west of the Florida Keys. See Table 1 for site details.

Table 1. List of sites with GPS locations. All sites were located within the boundaries of the Dry Tortugas National Park. Sites beginning with "I" were also located within the newly established Dry Tortugas Research Natural Area (RNA). Sites 1, 2, and 3 were located within the RNA and on the reef feature called Loggerhead Forest. Sites beginning with "O" were located outside of the RNA.

\begin{tabular}{lcc}
\hline Site name & Latitude & Longitude \\
\hline Site 1 & 24.66381 & -82.9270 \\
Site 2 & 24.66236 & -82.9274 \\
Site 3 & 24.67187 & -82.9230 \\
I-26 & 24.68404 & -82.8942 \\
I-33 & 24.69704 & -82.9065 \\
I-36b & 24.70824 & -82.8630 \\
I-38 & 24.65695 & -82.9274 \\
I-41 & 24.60459 & -82.9302 \\
I-44 & 24.68693 & -82.8832 \\
I-63 & 24.70715 & -82.8816 \\
O-12b & 24.70643 & -82.8381 \\
O-27 & 24.70318 & -82.8488 \\
O-42 & 24.57857 & -82.9645 \\
O-56 & 24.72122 & -82.8021 \\
O-72 & 24.69558 & -82.7899 \\
O-82 & 24.72231 & -82.8093 \\
O-84 & 24.57390 & -82.9258 \\
O-92 & 24.70643 & -82.8405 \\
O-94 & 24.72158 & -82.8069
\end{tabular}


$\mathrm{m}$ area video per transect. Video was processed to create $29-35$ continuous frames of $0.3 \times 0.4$ $\mathrm{m}$ area. The type of substrate under 10 random dots distributed on each frame was recorded to determine benthic cover as described by Miller et al. $(2007,2009)$. Scleractinian corals and macroalgae were identified to genus or species level. Other major biological groups identified included gorgonians, sponges, zoanthids, cyanobacteria (primarily Schizothrix spp.), and coralline algae.

All sites were revisited and resurveyed between 15 and 27 June, 2008, at which time we noted an unusually elevated occurrence of disease which was particularly abundant at Sites 1 and 2 , which were located on a high coral cover feature known as Loggerhead Forest. At that time an additional site, Site 3, was installed in the Loggerhead Forest region and a more intensive disease monitoring methodology was instituted at all sites. Specifically, disease lesions were counted within $1 \mathrm{~m}$ of either side of each transect and the species affected identified. Disease lesions were defined as bright white recently denuded areas of coral skeleton with no apparent algal colonization (Miller et al. 2009). Lesions were considered separate from each other if living tissue or old mortality (areas of denuded skeleton with dense algal colonization) appeared between them. From these data, we calculated lesion density per transect on each site visit. Disease prevalence (proportion of colonies affected) is a traditional measure of disease intensity, but was not calculated in our study because in several habitats colony boundaries were difficult to define and colony counts were unreliable, especially at sites with high densities of large corals of the Montastraea annularis (Ellis and Solander, 1786) complex-which includes M. annularis, Montastraea faveolata (Ellis and Solander, 1786), and Montastraea franksi (Gregory, 1895). However, lesion density has been used successfully as a measure of disease intensity in coral populations (Miller et al. 2009). Therefore, to provide an estimate of disease intensity relative to the abundance of potential hosts, we calculated disease lesions per area of living tissue by dividing the number of lesions per transect by the area of living tissue derived from applying the percent cover of living coral recorded for that transect to the area of the belt transect. Total living tissue cover was used in the calculation because all species identified in video transects have previously been reported to be affected by white plague or white plague-like diseases (Sutherland et al. 2004) and were therefore considered as potential host tissue area.

The three Loggerhead Forest sites (Sites 1, 2, and 3) were revisited 15-19 July, 2008, and resurveyed using both video transects and disease lesion density counts on a targeted expedition aimed at resurveying the disease outbreak. In June 2009, all 19 sites were revisited and all transects resurveyed using video and disease lesion density counts as part of the annual coral monitoring program.

Video images from sites 1, 2, and 3 taken in June 2008 were examined for the presence of lesion areas that could be tracked through time for potential regrowth of tissue. Lesion areas that were able to be re-identified in video images taken in July 2008 and June 2009 were examined for the identity of biological cover, specifically for the regrowth of new living tissue.

Physical Data.- - To assess potential anomalous physical conditions, we examined anomalous chlorophyll- $a$ concentration and turbidity (as angstrom coefficient 510 to $865 \mathrm{~nm}$ ) for the Dry Tortugas National Park in May-June of 2008 using the Ocean Biology Processing Group (OBPG) SeaWiFS global 9-km data products on these parameters (Giovanni Ocean Color Time-Series Online Visualization and Analysis: http://oceancolor.gsfc.nasa.gov/). We also examined temperature data from NPS data loggers (HOBO TEMP pro v2 temperature loggers, Onset Computer Corporation, Pocasset, MA) deployed in situ. Loggers were deployed at Sites 1 and 2 when those sites were established in May 2008, and additional loggers had been deployed at a similar depth since 2004 at Bird Key, located near Fort Jefferson and within $6 \mathrm{~km}$ of the Loggerhead Key sites. Temperature records from Bird Key were used to determine whether any temperature anomalies (high or low) had occurred in the DTNP region in the previous $4 \mathrm{yrs}$. 
Data Analysis.-To compare benthic cover types and lesion densities among months within 2008, we analyzed data collected at Sites 1 and 2 in May, June, and July using repeated measures Analysis of Variance (RM-ANOVA), and we used $t$-tests to compare benthic cover and lesion densities between June and July of 2008 at Site 3 where no May data were available. When data did not meet assumptions even after transformation, comparisons were analyzed with a Wilcoxon rank test. To compare lesion densities and benthic cover at all sites between June 2008 and June 2009, we used fully crossed two-way ANOVAs with site and year as factors in the model. Linear regression was used to examine the relationship between lesion density in June 2008 and benthic cover in 2008, including coral cover and macroalgae cover at sites with medium to high coral cover $(>5 \%)$. Sites with low coral cover $(<5 \%)$ were removed from the regression analyses because of the high abundance of zero lesion density data. All analyses were completed using the statistical software package JMP v. 9.0 (SAS Institute, Inc.).

\section{RESULTS}

Disease Description.-The disease signs observed in the present study were similar to those described for white plague (sensu Richardson et al. 1998b, 2001; Figs. $2-3$ ). The prominence of recently dead area on affected colonies (Fig. 2), with little or no algal colonization, indicated a rapid rate of progression as described by Woodley et al. (2008). Lesions were always located basally or peripherally on colonies, and they were found to be multifocal to coalescing with distinct undulating margins (description as recommended by Work and Aeby 2006). The appearance of basal/peripheral linear lesions and the apparent rapid tissue loss corresponded most closely with signs described for the diseases white plague type II (Richardson et al. 1998a,b) and III (Richardson et al. 2001). However, the recently denuded skeleton closest to the interface between dead skeleton and living tissue was sometimes covered by a thin white film (Fig. 3A,B), which is not characteristic of signs described for Caribbean white plague or any other "white disease" (Bythell et al. 2004). When apparent, the thin white film was found only on the recently denuded skeleton and not on living tissue. It appeared to be tenuously attached to the skeleton and was easily broken up and removed by gentle waving. Not all lesions displayed this film (Fig. 3C,D), although it occurred in approximately $50 \%$ of lesions.

Species affected included M. faveolata, M. franksi, Montastraea cavernosa Linnaeus, 1767, Colpophyllia natans (Houttuyn, 1772), Diploria labyrinthiformis (Linnaeus, 1758), Diploria strigosa (Dana, 1846), Mycetophyllia ferox Wells, 1973, Mycetophyllia lamarckiana Milne-Edwards and Haime, 1848, Agaricia agaricites (Linnaeus, 1758), Siderastrea siderea (Ellis and Solander, 1786), Dichocoenia stokesi Milne-Edwards and Haime, 1848, and Stephanocoenia intersepta (Lamarck, 1816). Species that were present but were not found to be affected included Porites astreoides Lamarck, 1816, Agaricia lamarcki Milne-Edwards and Haime, 1851, and Millepora spp. Colonies of Millepora spp. were rare and were not recorded in transects but were observed at the sites. Although no quantitative spatial data were collected, affected colonies of multiple species often appeared in clusters (Fig. 2).

Disease Dynamics.-When permanent transects were installed in May 2008, signs of the disease did not occur in video transects and signs of rapid tissue loss were rarely observed outside of transects (at most one to two colonies were affected at any site; M Brandt, pers obs) at any of the sites distributed throughout the park, including Loggerhead Forest. When revisited in mid-June, a high level of the disease 

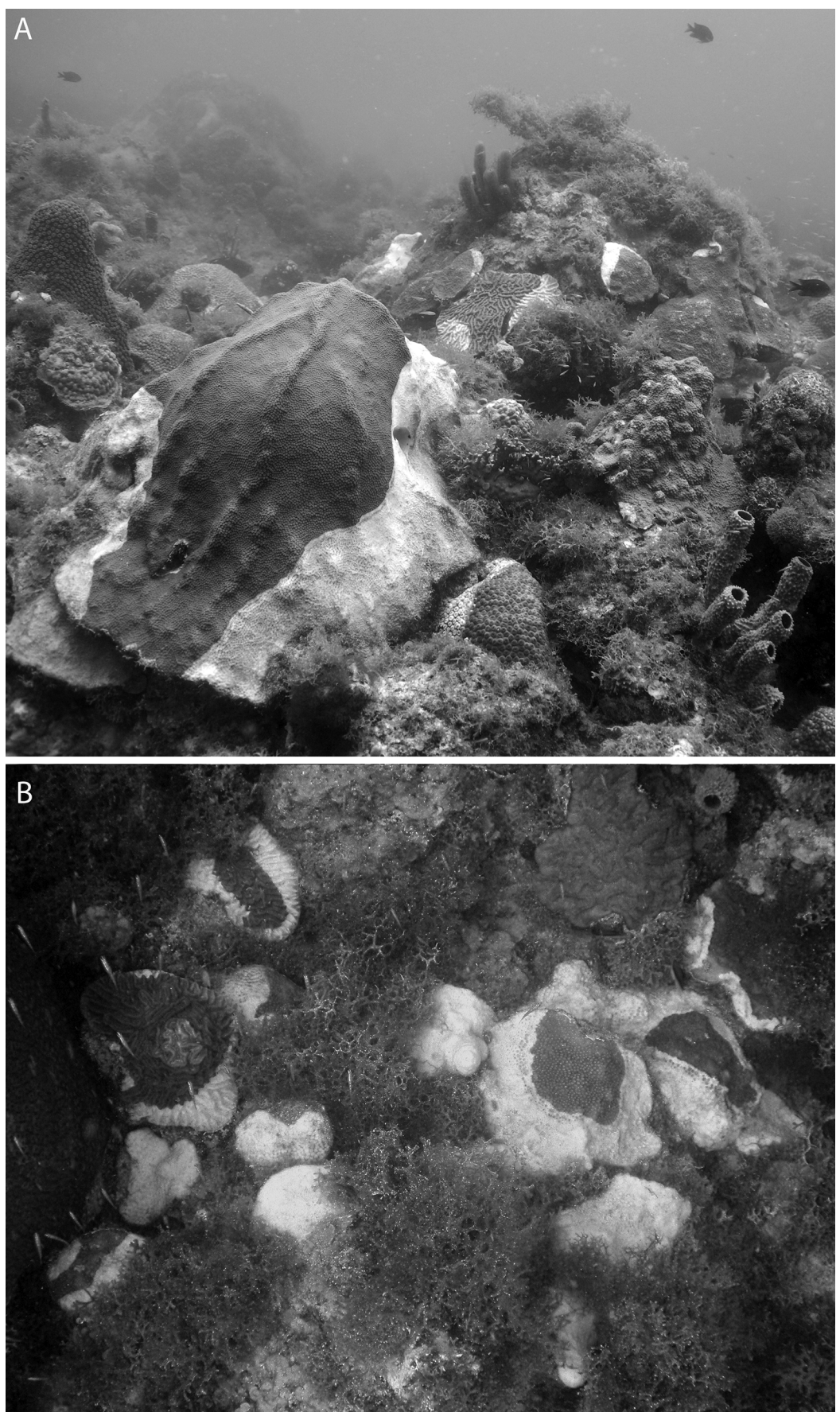

Figure 2. Photos taken in June 2008 at Sites 1 and 2 (A and B, respectively) of clusters of diseaseaffected colonies of multiple species of coral located in Dry Tortugas National Park, Florida. 

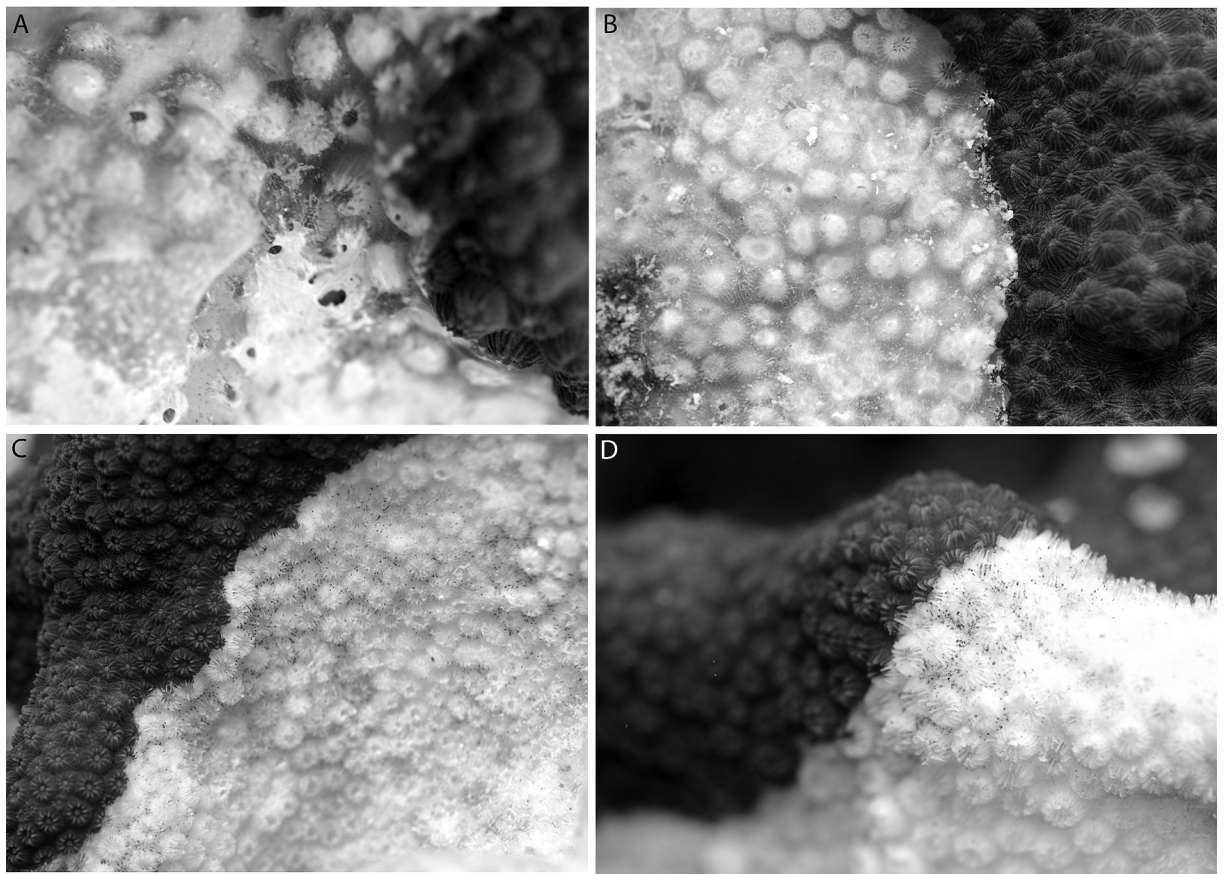

Figure 3. (A,B) Lesion margins on colonies of Montastraea faveolata displaying the white film overlaying recently denuded skeleton. The white film was thin and would easily dissolve and be removed through waving. (C,D) Lesion margins on colonies of $M$. faveolata where no white film was present on the recently exposed skeleton. Some small fragments of tissue were found near the lesion margin and can be seen as small specks in both photos.

was found at 13 of the sites (Fig. 4A,E). Disease lesions were most visibly dense on Loggerhead Forest sites (Sites 1, 2, and 3), where live coral cover was highest (up to 34\%; Fig. 4B).

A response team of scientists revisited Loggerhead Forest in July 2008 to resurvey Sites 1, 2, and 3 where disease appeared to be most concentrated in June. By this point, the outbreak appeared to have ceased and lesion densities were significantly lower at these three sites (Wilcoxon rank test; $P \leq 0.05$ for all three sites) when compared with June (Fig. 4A). Sites other than Loggerhead Forest sites were not visited in July due to logistical constraints, but disease levels at all sites were significantly different between June 2008 and June 2009 (two-way ANOVA: Year: $F=9.52, P<0.01$; Site: $F=2.4, P<0.01$; Site $\times$ Year: $F=0.99, P=0.48)$ and 11 of the 13 sites that had disease in 2008 had lower levels of disease in 2009 (Fig. 4E).

There were 84 identifiable lesions in images captured from video at sites 1,2 , and 3 in June 2008. Of these lesions, 36 lesion areas were able to be relocated in images from both July 2008 and June 2009. Of these, 31 lesions showed visible expansion of lesion area between June and July of 2008. All relocated lesions showed no recovery of tissue between 2008 and 2009. Instead, in 2009 four lesion areas were colonized by thick turf algae and the remaining lesion areas were covered by the macroalgae groups Dictyota spp. and/or Lobophora spp. 

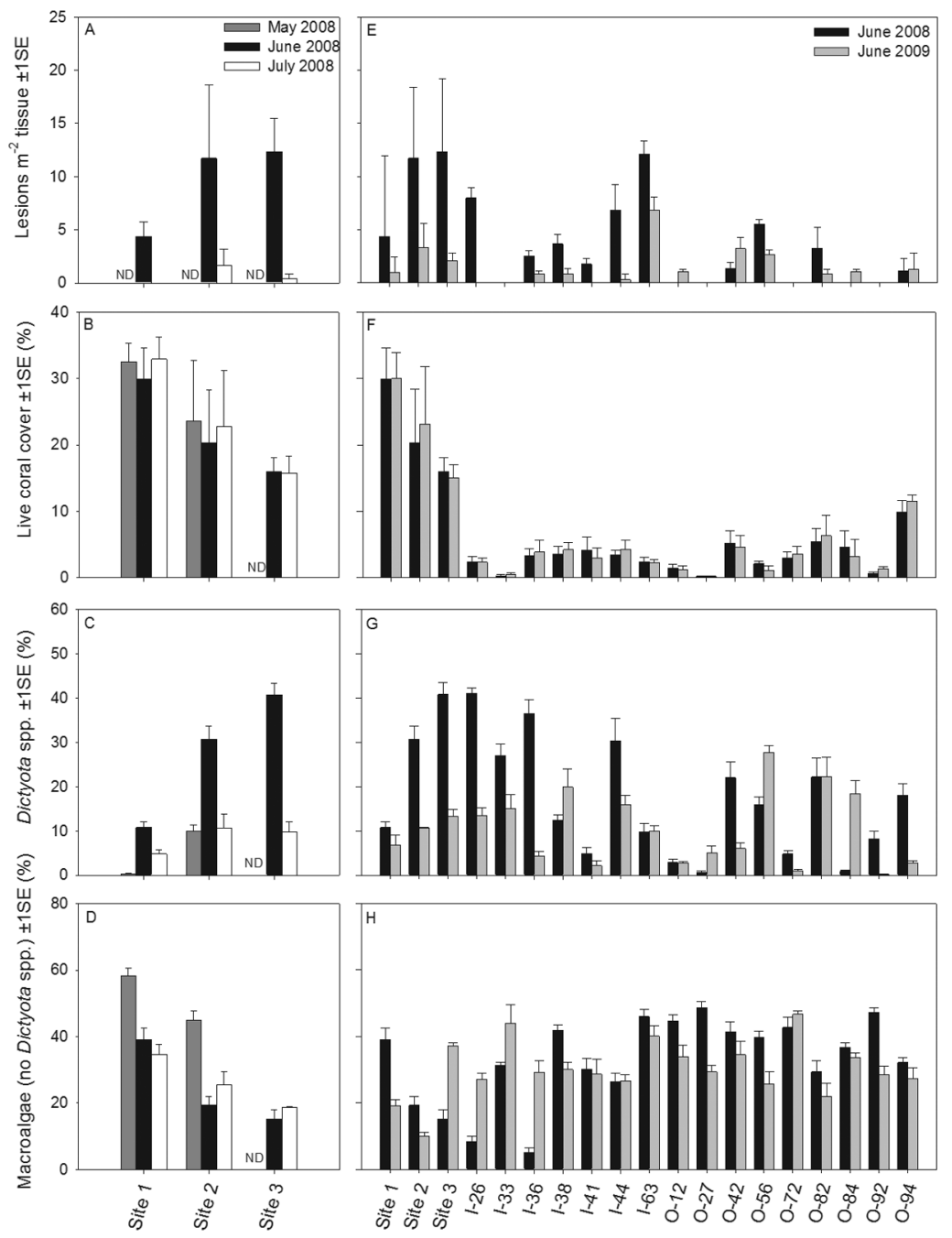

Figure 4. Temporal comparisons of (A) lesion density, (B) coral cover, (C) Dictyota spp. cover, and (D) macroalgae cover without Dictyota spp. in May, June, and July of 2008. Temporal comparisons of (E) lesion density, (F) coral cover, (G) Dictyota spp. cover, and (H) macroalgae cover without Dictyota spp. between June 2008 and June 2009. ND indicates no data were taken at that site for that time period (i.e., in May 2008 no lesion density data were collected at any site and no biological cover data were collected at Site 3). See Table 1 for site details.

Benthic Cover Dynamics.-Despite the high lesion density and perceived severity of the event, no change in coral cover was detected at Loggerhead Forest sites during the 3 mo of 2008 (Site 1: RM-ANOVA: $F=0.77, P>0.57$; Site 2: RM-ANOVA: $F=0.78, P>0.56$; Site 3: $t$-test: $t=-3.7, P>0.14$; Fig. $4 \mathrm{~B})$, and no changes in coral cover were detected at any sites between 2008 and 2009 (two-way ANOVA: Year: $F$ $=0.03, P>0.85$; Site: $F=18.9, P<0.001$; Site $\times$ Year: $F=0.1, P=1.0$; Fig. 4F). An a posteriori analysis of the sample design found that with the number of transects at each site $(n=4$ per site) and variability in coral cover among transects, only a change of coral cover of $\geq 10 \%, \geq 17 \%$, and $\geq 5 \%$ could be detected (with $\alpha=0.05$ and $\beta=0.80$ ) at sites 1, 2, and 3, respectively. The fluctuations in mean coral cover in Figure 4B and 
4F were therefore likely due to random variability in the placement of points on the video images and do not represent true change as indicated by the overlapping error bars between years. Increasing the numbers of points analyzed per transect, the number of frames analyzed per transect, or the number of transects per site potentially would increase the precision of coral cover estimates. However, the implementation of this design met the original SFCN monitoring goals of being able to detect a change of $25 \%$ after 5 yrs with $80 \%$ power (Miller et al. 2007).

Cover of the major biological groups identified did not change except for major algal groups which were broken into taxonomic groups, including Amphiroa spp., Dictyota spp., Halimeda spp., Lobophora spp., Sargassum spp., and other unidentified species. At sites 1 and 2, Dictyota spp. cover changed significantly across months in 2008 (RM-ANOVA site $1: F=24.2, P<0.05$; site $2: F=35.4, P<0.05$ ), increasing significantly between May and June and decreasing significantly between June and July (significant groups determined by Tukey post-hoc comparisons where $P<0.05$; Fig. 4C). At site 3, where disease severity was highest but where no May 2008 data were available, Dictyota spp. cover was higher in June and declined significantly in July (paired $t$-test: $t=-8.95, P<0.001$; Fig. $4 C$ ). Dictyota spp. cover was also significantly different between June 2008 and June 2009 (two-way ANOVA: Year: $F=$ 93.18, $P<0.001$ ), but differences were not consistent among sites as indicated by a significant effect of site and a significant interaction between site and year (Site: $F=$ 28.8, $P<0.001$; Site $\times$ Year: $F=18.9, P<0.001)$. However, at nine of the 13 sites that had disease in 2008, Dictyota was higher in 2008 vs 2009, and at seven of these sites Dictyota cover was at least twice as high in 2008 vs 2009 (Fig. 4G). All other macroalgae taxonomic groups showed no significant patterns. When overall macroalgae cover was considered with Dictyota spp. excluded, combined macroalgae cover did not change significantly among months in 2008 at sites 1 or 2 (Site 1: RM-ANOVA: $F=0.64, P=0.61$; Site 2: RM-ANOVA: $F=0.63, P=0.62$; Fig. $4 \mathrm{D})$ or between June and July 2008 at Site 3 (paired $t$-test: $t=1.15, P=0.83$; Fig. 4D). When all sites were considered together, macroalgae without Dictyota spp. differed significantly between June 2008 and June 2009 (two-way ANOVA: $F=526.5, P<0.001$ ), but differences were not consistent among sites (two-way ANOVA: Site: $F=17.1, P<0.001$; Site $\times$ Year: $F=8.6, P<0.001)$ and no overall patterns were obvious (Fig. $4 \mathrm{H})$.

Associations Among Lesion Density and Benthic Cover.-Lesion density was not significantly associated with living coral cover (Fig. 5A) or any other benthic cover $(P>0.05$, data not shown) except macroalgae cover, with which it was positively related (Fig. 5B). However, with Dictyota spp. removed, lesion density was no longer significantly related to macroalgae cover (Fig. 5C) and lesion density was positively and more strongly related to Dictyota spp. cover when considered on its own (Fig. 5D). No other algal cover type was significantly related to lesion density.

Physical Conditions.-Regional anomalies in chlorophyll- $a$ concentration and turbidity were near 0 between May and June 2008. Results were similar for the months January-May in 2008. Water temperature data from loggers installed in May 2008 at the Loggerhead Forest sites revealed no anomalous temperature differences between May, June, and July 2008, or in these months between 2008 and 2009. Temperatures at the Loggerhead Forest sites were all $<30{ }^{\circ} \mathrm{C}$ during May and June 2008 when the outbreak occurred. Additionally, Bird Key temperature loggers revealed no temperature anomalies (either high or low) during the preceding 2 yrs. Temperatures were slightly elevated in the fall seasons of $2004\left(\max 32^{\circ} \mathrm{C}\right)$ and 2005 $\left(\max 31^{\circ} \mathrm{C}\right)$. 

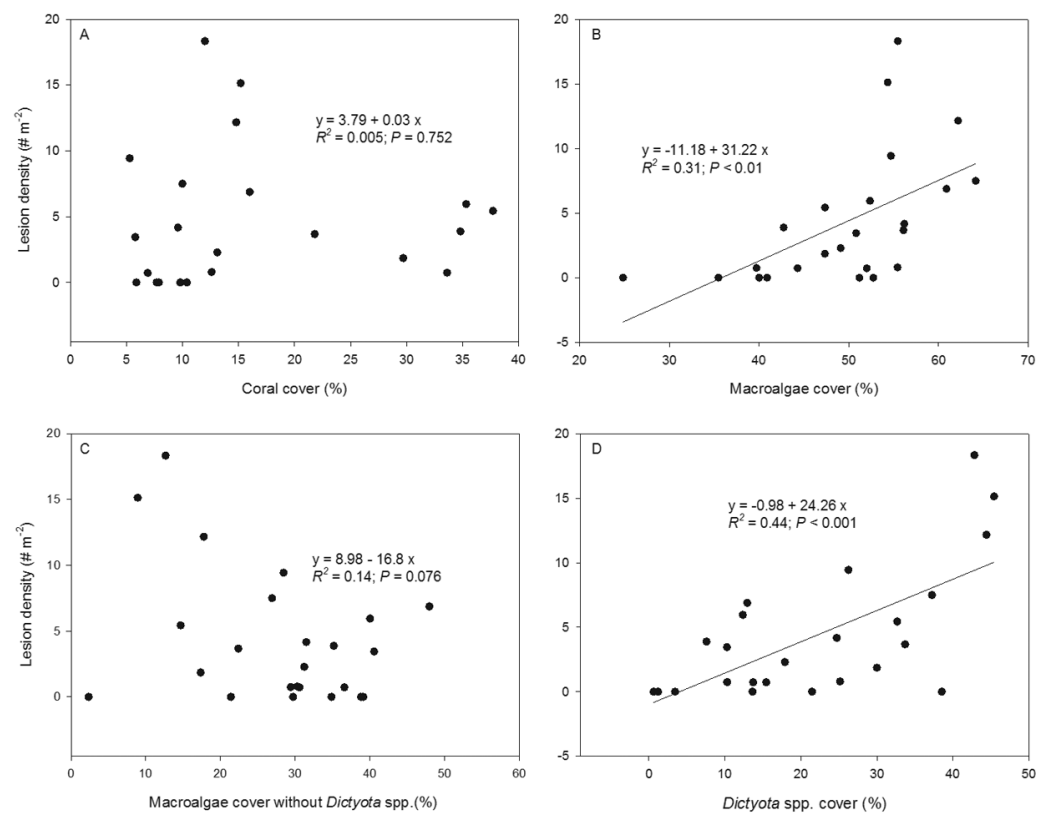

Figure 5. Relationships between lesion density and benthic cover of (A) live coral, (B) all macroalgae, (C) macroalgae without Dictyota spp., and (D) Dictyota spp. in June 2008. Lines are significant least square linear regressions.

\section{Discussion}

Dictyota spp. cover was positively related to lesion density during the peak of TMRTL levels in 2008 and its temporal dynamics were similar to that of the disease. This is the first time that a disease outbreak has been closely associated with dramatic changes in macroalgae cover suggesting that these two events were somehow linked, either through some interaction or as independent responses to a common factor. Both rapid tissue loss diseases and changes in Dictyota spp. cover have been independently linked to common physical phenomena. For instance, storm damage has been associated with outbreaks of rapid tissue loss syndromes in corals (Miller and Williams 2007) and they can also positively influence the proliferation of Dictyota spp. through fragmentation and reattachment (Tuomi and Vuorisalo 1989). However, no major storms passed through DTNP in the months leading up to the outbreak. Warmer oceans may also be increasing the abundances of disease in the marine environment by increasing pathogen growth rates and virulence while negatively impacting host susceptibility (Harvell et al. 2002) and temperature extremes have led to outbreaks of disease in other coral reef systems (Jones et al. 2004, Bruno et al. 2007, Heron et al. 2010). Warm temperatures are also known to postivitely affect the growth of Dictyota spp. (Lirman and Biber 2000). Temperatures in DTNP during our study were not anomalous and remained below the region-specific thermal threshold established for bleaching stress (Manzello et al. 2007), which is sometimes associated with disease (Brandt and McManus 2009). Some diseases and coral mortality have also been associated with higher levels of nutrients (Kuta and Richardson 
2002, Kuntz et al. 2005), which are known to influence macroalgae growth (Beach et al. 2006). DTNP sits in a remote section of the Florida Keys, removed from largescale anthropogenic eutrophication sources, and chlorophyll- $a$ concentrations (an indirect indicator of nutrient levels) derived from satellite data were not anomalously high. However, Loggerhead Key and Garden Key, two major land masses in DTNP, both receive some limited tourism and there is recreational boating activity in the area, both of which may affect water quality at small scales. The scale at which cholorophyll $a$ and turbidity were measured in our study was very coarse $(9 \mathrm{~km})$ and variability in these parameters at smaller scales, whether anthropogenically related or not, could have influenced biological activity in the area.

The co-occurrence of disease and Dictyota spp. also may have been the result of some interaction or potential synergy between the two factors. There is evidence that macroalgae can directly affect coral tissue, either by causing tissue mortality through the release of dissolved compounds (Smith et al. 2006) or hypoxia (Barott et al. 2012) or by initiating shifts in coral-associated bacterial communities to communities dominated by bacterial pathogens (Barott et al. 2012). Additionally, recent studies have documented a positive relationship between overall macroalgae abundance and microbial diversity and activity on reefs (Dinsdale et al. 2008, Haas et al. 2010), which could potentially influence the diversity and abundance of coral pathogens. Some studies have suggested a model whereby microbial activity stimulated by macroalgae growth further enhances coral mortality and algal growth in a positive feedback loop (Smith et al. 2006, Barott et al. 2012). This positive feedback may be a contributing or driving factor behind recent shifts on reef systems from coral-dominated to algal-dominated states (Smith et al. 2006, Barott et al. 2012). In the present study, an increase in Dictyota abundance could have contributed to increased overall microbial activity on the reef or shifts in microbial communities to dominance by virulent bacteria, which in turn led to the incidence of TMRTL. However, we found no evidence for a positive feedback between disease and continued expansion of algae cover. Instead, Dictyota cover had declined by July corresponding with the cessation of disease signs.

Dictyota could also have acted as a reservoir for the coral disease pathogen(s). As it increased in abundance, its probability of directly contacting coral tissue may have increased and this contact served as a vector for infection, resulting in a rapid incidence of disease lesions. In a comparison of bacterial communities among a coral $(M$. annularis) and four functional groups of benthic algae [encrusting calcifying algae, Halimeda opuntia (Linnaeus), turf algae, and Dictyota bartayresiana Lamouroux, 1809], the algal groups exhibited higher bacterial diversity than the coral species and D. bartayresiana in particular had the highest taxonomic richness (Barott et al. 2011). The abundance of coral disease-associated bacteria also was generally higher in the algal bacterial communities than in the coral bacterial communities (Barott et al. 2011). While previous experimentation in the field has demonstrated that the calcareous macroalga $H$. opuntia can act as a reservoir and potential vector for the white plague type II pathogen (Nugues et al. 2004), H. opuntia was not associated with lesions in our study and gross signs of the disease differed from those described in Nugues et al. (2004).

Despite the potential of the above microbial relationships, a causal relationship between Dictyota spp. abundance and disease incidence is not suggested by their temporal concordance. According to Hill's criteria for causation, a disease must be 
preceded by the causal factor in time (Hill 1965 as summarized by Plowright et al. 2008). Our results indicate that changes in Dictyota spp. abundance did not precede disease but occurred simultaneously, which suggests that the dynamics of the disease and algae were limited to co-occurrence and were not suggestive of a cause and effect relationship. However, a temporal pattern where macroalgae abundance increased prior to disease incidence could have occurred over a time span of several days to weeks but was not detected by the monthly sampling. Overall, it is unclear whether Dictyota spp. was a direct contributor to the disease outbreak or their co-occurrence was limited to responses to a common initiator. In the future, targeted microbial analysis, high frequency monitoring, and transmission experimentation could help determine the nature of the relationship between Dictyota spp. and TMRTL.

Important efforts have been made at predicting disease outbreaks through the analysis and modeling of relationships between disease and characteristics of their environment. On the Great Barrier Reef, outbreaks of white syndrome were found to be highly correlated with summer warm thermal anomalies and mild winters (Heron et al. 2010); and in Hawaii, disease levels were negatively associated with turbidity but positively associated with host abundance and potential vector abundance (Williams et al. 2010). We identified no anomalous environmental perturbations, but small scale variability may have played a role in the outbreak. Other significant coral disease events have occurred in the Caribbean in locations remote from human impacts and in the absence of measureable physical anomalies, but where monitoring of important environmental variables was not possible or constrained to coarse scale measurements (Croquer et al. 2003, Williams and Miller 2005) as in our study. Undetectable variability in factors that are potentially promoting outbreak conditions makes the development of such predictive models for these diseases difficult. Future monitoring efforts, including in DTNP, and disease studies should consider the incorporation of regular water quality sampling at the scale of reef monitoring activities, as this would likely provide greater insight into linkages between small scale environmental variability and disease activity.

Impacts from white plague outbreaks have been severe, with significant associated losses of coral cover (e.g., Nugues 2002, Miller and Williams 2007, Miller et al. 2009). However, disease impact in some of these reports have not been evaluated until many months to a year after the event (e.g., Croquer et al. 2003, Miller and Williams 2007), when other mortality sources may have interacted with disease to cause reductions in coral cover. In other studies, high frequency (i.e., monthly) monitoring of disease levels has revealed high levels of rapid tissue loss diseases persisting for many months, resulting in large declines in living coral (Nugues 2002, Miller et al. 2009). The temporal scale of the outbreak documented here was extremely short $(<1$ mo) by comparison and it is possible that the acute time frame resulted in comparatively little impact with no detectable change in overall coral cover. Additionally, we observed clusters of affected colonies, which may have resulted in areas of mortality in patches that were not detected by the number and spatial distribution of the randomly distributed transects. Lesions tracked through time in the video images did not regain tissue by 2009 , suggesting that partial mortality did occur. However, the total amount of partial mortality incurred by whole colonies could not be estimated because of the small spatial scale of the video. The width of coverage of the video transects was narrower $(0.4 \mathrm{~m})$ than the mean size of most colonies $(0.5-1 \mathrm{~m})$, and this made tracking of individual colonies in video records not feasible even though 
such records are thought to be the best method of evaluating the impact of a short lived event (Woodley et al. 2008). Future responses to outbreaks should consider the incorporation of colony tracking to determine colony-specific impacts and possible susceptibility factors as in Muller et al. (2008) and Brandt and McManus (2009).

The short duration of the event may help explain why no change in coral cover was recorded in the present study, but this event also raises questions about connections between our perception of the severity of disease events and their actual impact. Disease has increasingly been recognized as a major contributor to the loss of framework-building coral, particularly in the Caribbean where large scale events have dramatically changed reef structures throughout the region (Aronson and Precht 2001). Fewer studies have focused on understanding the long-term impacts from smallscale localized outbreaks (but see Edmunds 1991). Short events such as these may not result in immediate large losses of coral cover documented in longer-term outbreaks, but cumulative impacts may lead to significant declines in coral cover from multiple occurrences of such events through time. More information is needed on what determines the duration and spatial extent of an outbreak and consequently how these outbreaks contribute to the sustainability of coral populations and communities in the long term.

Ultimately, this study highlights the need for continued investigations into the physical and biological factors that influence disease patterns, including those affecting initiation, intensification, and cessation of disease in situ, with particular consideration to the spatial and temporal scales at which these factors operate. Overall, the difficulty of the coral reef research community to predict, respond to, and document acute events of this nature could be alleviated through the implementation of monitoring programs that are more comprehensively designed to include detailed environmental monitoring and with specific response plans to disease events such as these. Results from such programs could provide a greater understanding of the complicated conditions that lead to disease outbreaks.

\section{ACKNOWLEDGMENTS}

We are indebted to the staff at Dry Tortugas National Park and the crew of the M/V ForT JEFFERSON for permission to conduct this work and invaluable logistical support for field operations. We thank A Davis and M Eschevarria for assistance in the field and A Atkinson for advice on the manuscript. We also thank four anonymous reviewers for their valuable comments and suggestions.

\section{Literature Cited}

Aronson RB, Precht WF. 2001. White band disease and the changing face of Caribbean coral reefs. Hydrobiologia. 460:25-38. http://dx.doi.org/10.1023/A:1013103928980

Aronson R, Precht W. 2006. Conservation, precaution, and Caribbean reefs. Coral Reefs. 25:441-450. http://dx.doi.org/10.1007/s00338-006-0122-9

Barott KL, Rođriguez-Brito B, Janouskovec J, Marhaver KL, Smith JE, Keeling P, Rohwer FL. 2011. Microbial diversity associated with four functional groups of benthic reef algae and the reef-building coral Montastraea annularis. Environ Microbiol. 13:1192-1204. PMid:21272183. http://dx.doi.org/10.1111/j.1462-2920.2010.02419.x

Barott KL, Rodriguez-Mueller B, Youle M, Marhaver KL, vermeij M)A, Smith JE, Rohwer FL. 2012. Microbial to reef scale interactions between the reef-building coral Montastraea 
annularis and benthic algae. Proc Roy Soc B-Biol Sci. 279:1655-1664. PMid:22090385. http://dx.doi.org/10.1098/rspb.2011.2155

Beach KS, Waiters L), Borgeas HB. 2006. Irradiance and nutrient limitation of Dictyota spp. populations on Conch Reef, Florida Keys, USA. J Exp Mar Biol Ecol. 329:101-112. PMid:22715348. PMCid:3377904. http://dx.doi.org/10.1016/j.jembe.2005.08.010

Brandt ME, McManus JW. 2009. Disease incidence is related to bleaching extent in reef-building corals. Ecology. 90:2859-2867. PMid:19886494. http://dx.doi.org/10.1890/08-0445.1

Bruno JF, Selig ER, Casey KS, Page CA, Willis BL, Harveli CD, Sweatman H, Melendy AM. 2007. Thermal stress and coral cover as drivers of coral disease outbreaks. PLoS Biol. 5(6):12201227. PMid:17488183. PMCid:1865563. http://dx.doi.org/10.1371/journal.pbio.0050124

Bythell JC, Pantos O, Richardson L. 2004. White plague, white band, and other "white" diseases. In: Rosenberg E, Loya Y, editors. Coral Health and Disease. New York: Springer. p. 351-365.

Croquer A, Pauls SM, Zubillaga AL. 2003. White plague disease outbreak in a coral reef at Los Roques National Park, Venezuela. Rev Biol Trop. 51:39-45. PMid:15264552.

Denner EBM, Smith GW, Busse HJ, Schumann P, Narzt T, Polson SW, Lubitz W, Richardson LL. 2003. Aurantimonas coralicida gen. nov., sp. nov., the causative agent of white plague type II on Caribbean scleractinian corals. Int J Syst Evol Microbiol. 53:1115-1122. http:// dx.doi.org/10.1099/ijs.0.02359-0

Dinsdale EA, Pantos O, Smriga S, Edwards RA, Angly F, Wegley L, Hatay M, Hall D, Brown E, Haynes M, et al. 2008. Microbial ecology of four coral atolls in the Northern Line Islands. PLoS ONE. 3(2):e1584.

Edmunds PJ. 1991. Extent and effect of black band disease on a Caribbean reef. Coral Reefs. 10:161-165. http://dx.dol.org/10.1007/BF00572175

Gardner TA, Cote IM, Gill JA, Grant A, Watkinson AR. 2003. Long-term region-wide declines in Caribbean corals. Science. 301:958-960. PMid:12869698. http://dx.doi.org/10.1126/ science.1086050

Haas AF, Jantzen C, Naumann MS, Iglesias-Prieto R, Wild C. 2010. Organic matter release by the dominant primary producers in a Caribbean reef lagoon: implication for in situ O-2 availability. Mar Ecol Prog Ser. 409:27-39. http://dx.doi.org/10.3354/meps08631

Harvell CD, Mitchell CE, Ward JR, Altizer S, Dobson AP, Ostfeld RS, Samuel MD. 2002. Climate warming and disease risks for terrestrial and marine biota. Science. 296:21582162. PMid:12077394. http://dx.doi.org/10.1126/science.1063699

Heron SF, Willis BL, Skirving WT, Eakin CM, Page CA, Miller IR. 2010. Summer hot snaps and winter conditions: modelling white syndrome outbreaks on Great Barrier Reef corals. PLoS ONE. 5(8):e12210. PMid:20808912. PMCid:2923161. http://dx.doi.org/10.1371/ journal.pone.0012210

Hughes TP. 1994. Catastrophes, phase shifts, and large-scale degradation of a Caribbean coral reef. Science. 265:1547-1551. PMid:17801530. http://dx.doi.org/10.1126/ science.265.5178.1547

Jones RJ, Bowyer J, Hoegh-Guldberg O, Blackall LL. 2004. Dynamics of a temperature-related coral disease outbreak. Mar Ecol Prog Ser. 281:63-77. http://dx.doi.org/10.3354/ meps 281063

Kline DI, Vollmer SV. 2011. White band disease (type I) of endangered Caribbean acroporid corals is caused by pathogenic bacteria. Sci Rep. 1:7. PMid:22355526. PMCid:3216495. http://dx.doi.org/10.1038/srep00007

Kuta KG, Richardson LL. 2002. Ecological aspects of black band disease of corals: relationships between disease incidence and environmental factors. Coral Reefs. 21:393-398.

Kuntz NM, Kline DI, Sandin SA, Rohwer F. 2005. Pathologies and mortality rates caused by organic carbon and nutrient stressors in three Caribbean coral species. Mar Ecol Prog Ser. 294:173-180. http://dx.doi.org/10.3354/meps294173

Last JM. 2001. A dictionary of epidemiology. New York: Oxford University Press. 
Lirman D, Biber P. 2000. Seasonal dynamics of macroalgal communities of the northern Florida reef tract. Bot Mar. 43:305-314. http://dx.doi.org/10.1515/BOT.2000.033

Manzello DP, Berkelmans R, Hendee JC. 2007. Coral bleaching indices and thresholds for the Florida Reef Tract, Bahamas, and St. Croix, US Virgin Islands. Mar Pollut Bull. 54:19231931. PMid:17931666. http://dx.doi.org/10.1016/j.marpolbul.2007.08.009

Miller J, Muller EM, Rogers C, Waara R, Atkinson A, Whelan KRT, Patterson M, Witcher B. 2009. Coral disease following massive bleaching in 2005 causes $60 \%$ decline in coral cover on reefs in the US Virgin Islands. Coral Reefs. 28:925-937. http://dx.doi.org/10.1007/ s00338-009-0531-7

Miller J, Rogers C, Atkinson A, Muller E, Davis A, Loomis C, Patterson M, Waara R, Witcher B, Wright A, Petterson J. 2007. Coral reef monitoring protocol. Natural Resource Report NPS/ SFCN/NRR - 2007/XXX. 223 p.

Miller MW, Williams DE. 2007. Coral disease outbreak at Navassa, a remote Caribbean island.

Coral Reefs. 26:97-101. http://dx.do1.org/10.1007/s00338-006-0165-y

Muller EM, Rogers CS, Spitzack AS, van Woesik R. 2008. Bleaching increases likelihood of disease on Acropora palmata (Lamarck) in Hawksnest Bay, St John, US Virgin Islands. Coral Reefs. 27:191-195. http://dx.doi.org/10.1007/s00338-007-0310-2

Nugues MM. 2002. Impact of a coral disease outbreak on coral communities in St. Lucia: what and how much has been lost? Mar Ecol Prog Ser. 229:61-71. http://dx.doi.org/10.3354/ meps229061

Nugues MM, Smith GW, van Hooidonk RJ, Seabra MI, Bak RPM. 2004. Algal contact as a trigger for coral disease. Ecol Lett. 7:919-923. http://dx.doi.org/10.1111/j.1461-0248.2004.00651.x

Pantos O, Cooney RP, Le Tissier MDA, Barer MR, O’Donnell AG, Bythell)C. 2003. The bacterial ecology of a plague-like disease affecting the Caribbean coral Montastraea annularis. Environ Microbiol.5:370-382.PMid:12713463.http://dx.doi.org/10.1046/j.1462-2920.2003.00427.x

Plowright RK, Sokolow SH, Gorman ME, Daszak P, Foley JE. 2008. Causal inference in disease ecology: investigating ecological drivers of disease emergence. Front Ecol Environ. 6:420429. http://dx.doi.org/10.1890/070086

Pollock F), Morris PJ, Willis BL, Bourne DG. 2011. The urgent need for robust coral disease diagnostics. PLoS Pathogens. 7(10):e1002183. PMid:22028646. PMCid:3197597. http:// dx.doi.org/10.1371/journal.ppat.1002183

Richardson LL, Goldberg WM, Carlton RG, Halas JC. 1998a. Coral disease outbreak in the Florida Keys: Plague Type II. Rev Biol Trop. 46:187-198.

Richardson LL, Goldberg WM, Kuta KG, Aronson RB, Smith GW, Ritchie KB, Halas JC, Feingold JS, Miller SL. 1998b. Florida's mystery coral-killer identified. Nature. 392:557-558. http://dx.doi.org/10.1038/33302

Richardson LL, Smith GW, Ritchie KB, Carlton RG. 2001. Integrating microbiological, microsensor, molecular, and physiologic techniques in the study of coral disease pathogenesis. Hydrobiologia. 460:71-89. http://dx.doi.org/10.1023/A:1013187723831

Smith)E, Shaw M, Edwards RA, Obura D, Pantos O, Sala E, Sandin SA, Smriga S, Hatay M, Rohwer FL. 2006. Indirect effects of algae on coral: algae-mediated, microbe-induced coral mortality. Ecol Lett. 9:835-845. PMid:16796574. http://dx.doi.org/10.1111/j.1461-0248.2006.00937.x

Sutherland KP, Porter TW, Torres C. 2004. Disease and immunity in Caribbean and IndoPacific zooxanthellate corals. Mar Ecol Prog Ser. 266:273-302. http://dx.doi.org/10.3354/ meps 266273

Tuomi J, Vuorisalo T. 1989. What are the units of selection in modular organisms? Oikos. 54:227-233. http://dx.doi.org/10.2307/3565271

Ward JR, Lafferty KD. 2004. The elusive baseline of marine disease: are diseases in ocean ecosystems increasing? PLoS Biol. 2:542-547. PMid:15094816. PMCid:387283. http://dx.doi. org/10.1371/journal.pbio.0020120

Weil E, Smith G, Gil-Agudelo DL. 2006. Status and progress in coral reef disease research. Dis Aquat Organisms. 69:1-7. PMid:16703761. http://dx.doi.org/10.3354/dao069001 
Williams GJ, Aeby GS, Cowie ROM, Davy SK. 2010. Predictive modeling of coral disease distribution within a reef system. PLoS ONE. 5(2):1-10. PMid:20174663. PMCid:2822865. http://dx.doi.org/10.1371/journal.pone.0009264

Williams DE, Milier MW. 2005. Coral disease outbreak: Pattern, prevalence and transmission in Acropora cervicornis. Mar Ecol Prog Ser. 301:119-128. http://dx.doi.org/10.3354/ meps301119

Woodley CM, Bruckner AW, McLenon AL, Higgins JL, Galloway SB, Nicholson JH. 2008. Field manual for investigating coral disease outbreaks. NOAA Technical Memorandum NOS NCCOS 80 and CRCP 6. NOAA, Silver Spring, MD. 85 p.

Work TM, Aeby G. 2006. Systematically describing gross lesions in corals. Dis Aquat Organisms. 70:155-160. PMid:16875402. http://dx.doi.org/10.3354/dao070155

Date Submitted: 23 September, 2011.

DATE ACCEPTED: 20 July, 2012.

Available Online: 11 September, 2012.

Addresses: (MEB) Center for Marine and Environmental Studies, University of the Virgin Islands, 2 John Brewer's Bay, St. Thomas, Virgin Islands 00802. (BIR) National Marine Fisheries Service, Southeast Fisheries Science Center, 75 Virginia Beach Dr., Miami, Florida 33149. (RW, BW, MP) National Park Service, South Florida/Caribbean Inventory and Monitoring Network, 18001 Old Cutler Rd., Palmetto Bay, Florida 33157. (JM, AJE) National Park Service, South Florida/Caribbean Inventory and Monitoring Network, 1300 Cruz Bay Creek, St. John, Virgin Islands 00830. Corresponding Author: (MEB) Email: <mbrandt@uvi.edu>.

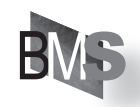

